\title{
BUROCRACIA BRASILEIRA, REFORMA ADMINISTRATIVA E ESTADO NOVO: O PAPEL DO APARATO ADMINISTRATIVO NO GOVERNO VARGAS
}

\author{
EMERSON AFFONSO DA COSTA MOURA ${ }^{\dagger}$
}

RESUMO: O papel exercido pelo aparato administrativo através do Departamento Administrativo do Serviço na política do Governo Vargas é o objeto posto em debate, a partir da investigação do contexto patrimonialista, autoritário e ineficiente que marca a formação e desenvolvimento da burocracia administrativa, das propostas de profissionalização e eficiência trazidas pelas reformas administrativas da década de 1930 e 1940 com a contraposição das limitações da importação do modelo weberiano no contexto brasileiro e da análise da criação do DASP no Estado Novo e suas atribuições, definindo a função de controle que exerceu de forma direta e através dos Departamentos Estaduais na Administração Pública Brasileira garantindo a política centralizadora e desenvolvimentista do governo.

Palavras-Chave: Administração Pública; Reforma Administrativa; Burocracia; Estado Novo; DASP.

\footnotetext{
${ }^{\dagger}$ Doutorando em Direito pela Universidade do Estado do Rio de Janeiro (UERJ). Mestre em Direito Constitucional e Especialista em Direito da Administração Pública pela Universidade Federal Fluminense (UFF). Professor Contratado de Direito Administrativo dos Cursos da Graduação da UFF e da UFRJ e Palestrante Convidado dos Cursos da Escola de Magistratura do Estado do Rio de Janeiro (EMERJ) e Escola Superior de Advocacia da Ordem dos Advogados Brasileiros. Membro da Comissão de Direito Administrativo do Instituto dos Advogados Brasileiros (IAB). Advogado no Rio de Janeiro. E-mail: emersonacmoura@yahoo.com.br.
} 


\begin{abstract}
The role played by the administrative apparatus through the Department of Administrative Services in the Government policy Vargas is the object put in debate. Analyzes the theme from the the investigation of patrimonial, authoritarian and inefficient context which marks the formation and development of administrative bureaucracy, the tenders of professionalization and efficiency brought by the administrative reforms of the 1930s and 1940s with the contrast of the limitations of the import of the Weberian model in the Brazilian context and analysis of the establishment of the New State DASP and their assignments. Search the work demonstrate the control position he held directly and through the State Departments in the Brazilian Public Administration ensuring centralized and developmental policy of the government. For this is adopted as the research method of approach structuralism in order to identify the deconstruction of the phenomenon - of administrative reforms - in the superficial perception - the proposed impersonality and efficiency as the best way of achieving the public interest - its invariant structure - the search for the adequacy of the administrative apparatus and bureaucracy for pursuit of political ends pursued by the Government.
\end{abstract}

KeYWORDS: Public Administration; Administrative Reform; Bureaucracy; Vargas' New State; Administrative Department of Public Service. 


\section{SUMÁRIO:}

I. INTRODUÇÃ

II. BUROCRACIA BRASILEIRA .....................................................371

III. REFORMAS ADMINISTRATIVAS NO GOVERNO VARGAS.................379

IV. A CRIAÇÃo do DASP E O SEU PAPEL NO GOVERNO VARGAS ........387

V. CONCLUSÃO ...............................................................................395

VI. REFERÊNCIAS ........................................................................396

\section{TABLE OF CONTENTS:}

I. INTRODUCTION .................................................................................370

II. BRAZILIAN BUREAUCRACY ..............................................................371

III. REFORMS IN THE VARGAS ADMINISTRATION ..................................379

IV. THE CREATION OF DASP AND ITS ROLE IN THE

VARGAS ADMINISTRATION...........................................................387

V. CONCLUSION ...........................................................................395

VI. REFERENCES ..................................................................................396 


\section{INTRODUÇÃO}

Com a ascensão do Governo de Getúlio Vargas no século XX surgem as primeiras reformas administrativas que buscavam superar o modelo oligárquico e patrimonialista que dominavam a Administração Pública Brasileira, mediante a tentativa de adoção do modelo burocráticoracional de Weber, capaz de atribuir maior grau de impessoalidade e eficácia na atuação administrativa.

Não obstante, verifica-se que, com as reformas da década de 1930 e 1940 gerou-se um desenho institucional marcado pela centralização administrativa no Governo Federal com a concessão de amplas atribuições concedidas aos seus órgãos, em especial o Departamento Administrativo do Serviço, que não só não atingiram os fins propostos como denotaram a utilização da elite burocrática como aparato de realização da política do Estado Novo.

Busca o presente trabalho, portanto, investigar qual foi o papel exercido pelo aparato administrativo, em específico, por meio do Departamento Administrativo do Serviço (DASP) em decorrência das reformas administrativas realizadas durante o Governo Vargas, como instrumento da política de centralização, controle e desenvolvimento nacional exercida pelo Governo Vargas no Estado Novo.

De início, analisa-se o contexto de formação das instituições e burocracia administrativa brasileira ainda no Período Colonial, de forma a fixar mediante a permanência dos caracteres patrimonialista, autoritário e ineficiente no exercício da atividade administrativa, bem como a influência perniciosa do poder político no aparato administrativo ainda sob o signo da República, aos quais buscaram as reformas administrativas de Vargas elidir.

Após, volta-se o estudo às reformas administrativas da década de 1930 e 1940 de forma a verificar se as suas propostas de impessoalidade e eficiência na Administração Pública, bem como dos modelos importados, dentre os quais da burocracia-racional de Weber, foram capazes de gerar a superação daqueles paradigmas e a profissionalização da burocracia ou importaram na formação de uma dualidade na Administração com a manutenção do clientelismo.

Por fim, centra-se o trabalho na criação do DASP no Estado Novo, bem como nas reformas que importaram na ampliação de suas atribuições e a criação de Departamentos Estaduais vinculados a este, de forma a determinar o papel central desenvolvido pela Administração Pública Brasileira por meio deste órgão como instrumento da política centralizadora e desenvolvimentista do governo.

Para tanto, utiliza-se como método de abordagem da pesquisa o 
estruturalismo, de forma a identificar na desconstrução do fenômeno das reformas administrativas - sob a percepção superficial - da proposta de impessoalidade e eficácia como melhor forma de consecução do interesse público - a sua estrutura invariante - a busca pela adequação do aparato administrativo e da burocracia para persecução dos fins políticos almejados pelo Governo.

\section{BUROCRACIA BRASILEIRA}

Como cediço, a colonização na América, com terras tidas primitivas e uma população considerada inaproveitável, tinha como objetivo a ocupação com fins comerciais, sendo a formação de um corpo de agentes - de funcionários e militares - e a organização - em feitorias - destinada apenas a garantir a defesa, explorar os recursos naturais e servir de articulação entre as rotas marítimas e os territórios ocupados. ${ }^{1}$

Submetido à Administração Metropolitana, o Brasil não correspondia a uma unidade, mas parte de um conjunto de colônias, "províncias" ou "capitanias" - como as províncias do reino de Portugal e do Algarve, os estabelecimentos da África e do Oriente - que integra a monarquia portuguesa e estava sujeita à Administração Geral das Capitanias através do Conselho Ultramarino que entrava no conhecimento dos assuntos coloniais. $^{2}$

Neste sentido, a Administração Colonial efetivamente se assenta e se entrosa em apenas uma única "noção ampla e geral" de monarquia portuguesa que abrange desde o rei - enquanto supremo chefe representante de Deus que regula todas as atividades - até o último de seus súditos e vassalos que exercem um papel, mesmo que modesto, no organismo político da monarquia ${ }^{3}$.

O "poderio" da nobreza se demonstra desde o monopólio dos cargos públicos até a influência nas decisões políticas através dos Conselhos da Coroa, na posição privilegiada nas questões penais onde o título de nobre reduzia a pena até todas as "portas" concedidas à mesma. Ao contrário, a grande massa da nação, a qual não eram concedidos direitos pessoais,

1 PRADO JUNIOR, Caio. Formação do Brasil Contemporâneo: colônia. São Paulo, SP: Companhia das Letras, 2011, p. 20

2 PRADO JUNIOR, Caio. Formação do Brasil Contemporâneo: colônia. São Paulo, SP: Companhia das Letras, 2011, p. 322.

${ }^{3}$ PRADO JUNIOR, Caio. Formação do Brasil Contemporâneo: colônia. São Paulo, SP: Companhia das Letras, 2011, p. 318.

2 JOURNAL OF INSTITUTIONAL STUDIES 1 (2016) 
nunca teve "peso" em questões importantes da Administração Colonial. ${ }^{4}$ O processo de colonização Europeia foi mais intenso no Brasil do que em qualquer parte da América, em um modelo aristocrático, patriarcal e escravocrata, onde tudo se deixou à iniciativa particular: os gastos de instalação, os encargos de defesa e os privilégios de mandos sobre a Colônia foram deixados ao "português que fez-se aqui senhor de terras mais vastas, dono de homens mais numerosos que qualquer outro colonizador da América". 5

Isso se torna claro na adoção do modelo de organização administrativa de sistema de capitanias que dividia o território em grandes faixas de terra doadas de forma individual, intransferível e transmissível por herança a membros da nobreza de Portugal com fins de colonização, evitando as ameaças externas e exploração, permitindo a apropriação das riquezas naturais, aos quais eram atribuídas além das terras, competências tipicamente estatais.

Enquanto "concessões do poder público a particulares", as capitais importavam nas significativas atribuições governamentais que eram delegadas ao donatário, como as de natureza judiciária - aplicação da justiça civil e criminal, inclusive, com a imposição de pena de morte fiscal - arrecadação de tributos devido à Coroa - e administrativas - fundação de vilas, nomeação de funcionários e distribuição de terras entre colonos. ${ }^{6}$

Ademais, os Capitães-Donatários gozavam de privilégios econômicos, como o direito de explorar as minas, ressalvado o quinto real; o aproveitamento do pau-brasil dentro do país; a liberdade de exportação para o reino, exceto de escravos que eram restritos a certos números; direitos preferenciais que os protegiam da concorrência estrangeira; entrada livre de mantimentos e qualquer munição de guerra; e liberdade de comunicação entre as capitanias. ${ }^{7}$

Note, portanto, que a organização dada à atividade administrativa no Brasil Colônia é marcada pela confusão entre público e privado, na figura do nobre que exercia o papel de colono e a função de exploração

${ }^{4}$ ABREU, João Capistrano de. Capítulos de História Colonial (1500-1800). Brasília, DF: Conselho Editorial do Senado Federal, 1998, p. 27.

${ }^{5}$ FREYRE, Gilberto. Casa-grande \& senzala: formação da família brasileira sob o regime da economia patriarcal. $48^{\mathrm{a}}$ ed. Recife, PE: Fundação Gilberto Freyre, 2003, p. $158-159 / 187$.

${ }^{6}$ WEHLING, Arno; WEHLING, Maria José C de M. Formação do Brasil Colonial. Rio de Janeiro, RJ: Editora Nova Fronteira, 1994, p. 67.

7 ABREU, João Capistrano de. Capítulos de História Colonial (1500-1800). Brasília, DF: Conselho Editorial do Senado Federal, 1998, p. 49. 
econômica e de governador que exercia atribuições sobre a colônia, administrando as mesmas terras como fazenda e província, usando ora privilégios de comerciante e ora competências públicas.

Esse sistema adotado no Brasil Colônia de um "feudalismo renascido na América" onde o senhor de latifúndios e de escravos "se incorpora" a uma categoria social - a aristocracia ou nobreza de ordem rural - resultou em "um trânsito entre os estados", em "estratificação ascendente": da riqueza à aristocracia e da aristocracia ao poder político, que fixava, nas casas senhoriais, a autoridade política, anuladas as "mãos do rei pela distância" .8

As relações entre os capitães-governadores e a Coroa eram de cunho capitalista e caráter patrimonial, sendo o donatário caracterizado pela natureza dupla, de fazendeiro e autoridade, cujos colonos copiavam seu modelo, obedecendo não ao impulso de povoar e colonizar, mas de usar e esgotar a terra, arrecadando riqueza e garantindo o retorno à Portugal para a vida "opulenta da corte, nas glórias de mandar e se fazer respeitado". ${ }^{9}$

O modelo inicial de organização administrativa da Colônia era marcado, portanto, por uma "ausência completa de um sistema regular e complicado de Administração", com a inexistência de qualquer "regulamentação vexatória" que impedisse a liberdade de ação dos colonizadores, que criou as condições favoráveis para o desenvolvimento agrícola e para a expansão econômica. ${ }^{10}$

Após, como permanece produtivo o negócio para a Coroa, renova-se a autoridade, agora real com a centralização administrativa e com a absorção da autoridade dos capitães donatários, na figura do governador-geral, que reduzia o espaço econômico ao espaço administrativo, mantendo "o caranguejo agarrado à praia" e garantindo que a colonização estava ao alcance do controle e repressão da metrópole. ${ }^{11}$

Assim, substitui-se o mecanismo de uma Administração Colonial "frouxa", deixando à vontade as colônias e o poder ao donatário, pela criação do Governo-Geral assegurando a união das capitanias

${ }^{8}$ FAORO, Raymundo. Os Donos do Poder: a formação do patronato político brasileiro. São Paulo, SP: Editora Globo, 2001, p. 155.

${ }^{9}$ FAORO, Raymundo. Os Donos do Poder: a formação do patronato político brasileiro. São Paulo, SP: Editora Globo, 2001, p. 158/166-167.

${ }^{10}$ BEAULIEU-LEROY. De La Colonisation Chez Le Peuples Modernes. Paris: Guillaumin Et Cie Libraires, 1882, p. 54.

${ }^{11}$ FAORO, Raymundo. Os Donos do Poder: a formação do patronato político brasileiro. São Paulo, SP: Editora Globo, 2001, p. 158/167-170. 
conservando-as sobre o domínio da metrópole, impedindo que a consciência nacional sobrepujasse à regional, o que fatalmente ocorria resultado da "absoluta igualdade de tratamento e de regime administrativo". ${ }^{12}$

O aparelho político-administrativo na Colônia tinha o objetivo de extração da riqueza e produção, que repetiram as estruturas da nações ibéricas: o Estado como "órgão de opressão", com seus "privilégios e exércitos de servidores" e uma máquina administrativa reduzida ao fisco e defesa, que nada fizeram para aperfeiçoar os serviços públicos e cujas poucas tentativas foram inúteis diante do parasitismo. ${ }^{13}$

Enquanto "organismo à parte" da Colônia com interesses particulares "e até radicalmente opostos aos interesses das novas sociedades", as autoridades representam o poder alheio, independente e que domina a nacionalidade nascente, fazendo valer por meio de suas prerrogativas a imposição da vontade absoluta e soberana do governo, garantindo a realização dos interesses da metrópole sobre os da Colônia. ${ }^{14}$

Os órgãos político-administrativos do Brasil eram as instituições arcaicas da península, adaptadas ao "parasitismo sobre as colônias": o Estado apenas atua para

cobrar e coagir e punir aqueles que se neguem a pagar ao governo centralizador, absolutista, monopolizador. A justiça aparece para condenar os que se rebelam contra o Estado ou contra os parasitas criados e patrocinados por ele. ${ }^{15}$

O Estado, portanto, na Colônia não atua em benefício da população. As atividades - o fisco, a defesa, a justiça e administração colonial - são ligadas à geração de riqueza para a Metrópole e manutenção da ordem para garanti-la. Além desta, "não há mais nada: nem polícia, nem higiene, nem proteção ao fraco, nem garantias, nem escolas, nem obras de interesse público", nada que represente a ação dos poderes públicos em

${ }^{12}$ FREYRE, Gilberto. Casa-grande \& senzala: formação da família brasileira sob o regime da economia patriarcal. $48^{a}$ ed. Recife, PE: Fundação Gilberto Freyre, 2003, p. 92.

${ }^{13}$ BOMFIM, Manoel. A América Latina: males de origem. Rio de Janeiro, RJ: Centro Edelstein de Pesquisas Sociais, 2008, p. 100-101.

${ }^{14}$ BOMFIM, Manoel. A América Latina: males de origem. Rio de Janeiro, RJ: Centro Edelstein de Pesquisas Sociais, 2008, p. 143-144.

${ }^{15}$ BOMFIM, Manoel. A América Latina: males de origem. Rio de Janeiro, RJ: Centro Edelstein de Pesquisas Sociais, 2008, p. 101-102. 
prol da sociedade. ${ }^{16}$

Por esta razão, negligenciada pela Coroa que via na Administração Colonial apenas o objetivo fiscal, os atos de administração ou de administradores, salvo exceções, voltavam-se meramente à percepção de tributos, de forma que a "mercantilização brutal dos objetivos da colônia contaminará a todos" e o construtivo da Administração é relegado para um segundo plano. ${ }^{17}$

As atividades administrativas essenciais eram executadas de forma "lamentável": Administração da Justiça era cara, morosa e complicada, a segurança pública precária, as finanças públicas em déficit pela falta de arrecadação adequada e crescimento das despesas, a instrução pública reduzida aos centros e ministrado pelas ordens religiosas, os serviços de higiene e saúde pública não existiam nas principais cidades. ${ }^{18}$

A imoralidade e a corrupção dominavam a Administração Pública: os cargos públicos eram "obtidos e vendidos como a mais vulgar mercadoria" e para agravar com "métodos aceitos e reconhecidos" e o peculato, o suborno e todas as demais formas de corrupção administrativa eram práticas gerais e universalizadas que já passaram para a "essência da Administração Colonial". ${ }^{19}$

Embora haja a separação entre Administração Pública da Casa Real com a realização de tarefas públicas, a distinção entre elas é tênue, pois é a Corte que se transforma em funcionário ou soldado em um "processo de nobilitação, que abrange o letrado e o homem de armas", ocupando cargos que num sistema patrimonial, é mais "um negócio a explorar, um pequeno reino a ordenhar, uma miga a aproveitar".$^{20}$

À luz ainda do absolutismo, se infundia um caráter despótico: a impessoalidade nas relações entre autoridade e súdito, a existência de competências limitadas e controle hierárquico é "obra do futuro; do distante e incerto futuro". O sistema é aberto ao acesso pelo rei apenas aos poderosos em um modelo onde "manda quem pode e obedece quem tem juízo" sem que haja "fortaleza dos direitos individuais, armados

${ }^{16}$ BOMFIM, Manoel. A América Latina: males de origem. Rio de Janeiro, RJ: Centro Edelstein de Pesquisas Sociais, 2008, p. 102.

17 PRADO JUNIOR, Caio. Formação do Brasil Contemporâneo: colônia. São Paulo, SP: Companhia das Letras, 2011, p. 358.

18 PRADO JUNIOR, Caio. Formação do Brasil Contemporâneo: colônia. São Paulo, SP: Companhia das Letras, 2011, p. 355.

${ }^{19}$ PRADO JUNIOR, Caio. Formação do Brasil Contemporâneo: colônia. São Paulo, SP: Companhia das Letras, 2011, p. 356-357.

${ }^{20}$ FAORO, Raymundo. Os Donos do Poder: a formação do patronato político brasileiro. São Paulo, SP: Editora Globo, 2001, p. 199. 
contra o despotismo e o arbítrio". ${ }^{21}$

Dessa relação entre aristocracia rural e burocracia estatal, entre detentores do poder econômico que exercem sobre os subalternos e de titulares do poder público que exercem sobre os colonos, a rigor, as mesmas pessoas, nota-se que o exercício da função pública acaba antes se vinculando com a noção de autoridade do que de competência, de prerrogativas do que de deveres, de satisfação dos interesses privados do que da coletividade em geral.

A função pública torna-se "instrumento regalista da classe dominante", que forma um "patriciado administrativo", que "congrega, reúne e domina a economia". O cargo público é título que confere ao seu portador uma autoridade ou "marca de nobreza" pois concedido apenas ao homem tido como de "limpo sangue" ou de "boa linhagem" conforme aduz as Ordenações Filipinas ou os "homens bons" nas câmaras. ${ }^{22}$

De tal modo, o quadro administrativo era formado por uma minoria que "comandava, disciplinava e controlava" a vida econômica e social, mantendo-se e se articulando sobre uma estrutura de classe, que ao mesmo tempo que influenciava o estamento, deste recebia o influxo político configurador, sendo seu patrimonialismo haurido da "seiva" da conjectura econômica da expansão comercial de Portugal. ${ }^{23}$

$\mathrm{O}$ "patriciado burocrático" era a cúpula que presidia e regia a vida colonial: a burocracia civil com seus funcionários governamentais e exatores; a militar com seus corpos de defesa e de repressão; e a eclesiástica, regulando os negócios terrenos. Junto com o setor empresarial e mercantil, formou a "elite dominante da colônia," que atuou como "agente de sua própria prosperidade" e reitora "do processo de formação do povo brasileiro"..$^{24}$

Em um ambiente marcado pela família patriarcal, os detentores de posições públicas de responsabilidade não conseguiam compreender a distância fundamental entre os domínios do privado e do público: como a gestão representava assunto de interesse particular, as funções, os empregos e os benefícios eram usados para interesses pessoais do

${ }^{21}$ FAORO, Raymundo. Os Donos do Poder: a formação do patronato político brasileiro. São Paulo, SP: Editora Globo, 2001, p. 200.

${ }^{22}$ FAORO, Raymundo. Os Donos do Poder: a formação do patronato político brasileiro. São Paulo, SP: Editora Globo, 2001, p. 203-205.

${ }^{23}$ FAORO, Raymundo. Os Donos do Poder: a formação do patronato político brasileiro. São Paulo, SP: Editora Globo, 2001, p. 242.

${ }^{24}$ RIBEIRO, Darcy. O Povo Brasileiro: A Formação e o Sentido do Brasil. São Paulo, SP: Companhia das Letras, 1995, p. 178. 
funcionário, e não nos interesses dos cidadãos..$^{25}$

O regime administrativo brasileiro se estrutura, portanto, ainda na Colônia, a partir de um modelo patrimonialista, autoritário e ineficiente da Administração Pública, sendo marcada a ação administrativa ante pela satisfação dos interesses econômicos da Coroa e privados da burocracia aristocrática, do que pela prossecução das necessidades coletivas da sociedade colonial emergente. ${ }^{26}$

Sob um prisma, a dominação patrimonial se exterioriza na inexistência de igualdade jurídica e de garantias institucionais contra o arbítrio. Há uma dependência do indivíduo ao poder da autoridade - exercida pelo soberano e seu quadro administrativo - que controla diretamente os recursos econômicos e militares, em uma indissociação entre o patrimônio público e privado. ${ }^{27}$

De outro, a autocracia autoritária do poder central e do quadro administrativo que comanda a economia, as forças militares e o aparelho burocrático condiciona ao seu comando os indivíduos, mantado pelo dever de lealdade ao soberano. Neste contexto, impõe-se à sociedade uma orientação "de cima e do alto" obedecendo o comando do poder: não é a sociedade que dita ao poder público a política, mas a política que dita as suas condutas. ${ }^{28}$

Por fim, a ineficiência se exterioriza na falta de organização e presteza do funcionamento da Administração, adoção de processos autoritários como o recrutamento e a cobrança de tributos, a confusão entre competências dos agentes, o excesso de burocracia dos órgãos centrais com funcionalismo inútil e a centralização administrativa na Coroa torna "monstruosa, emperrada e ineficiente a máquina burocrática que é a "administração colonial." ${ }^{29}$

${ }^{25}$ HOLANDA, Sérgio Buarque de. Raízes do Brasil. 17a ed. Rio de Janeiro, RJ: J. Olympio Editora, 1984, p. 145-146.

${ }^{26}$ Sobre a evolução do regime administrativo brasileiro, vide: MOURA, Emerson Affonso da Costa. Um Fundamento do Regime Administrativo: O Princípio da Persecução do Interesse Público. Dissertação (Mestrado em Direito Constitucional) Programa de Pós-Graduação em Direito Constitucional, Universidade Federal Fluminense, Niterói, 2014.

${ }^{27}$ FAORO, Raymundo. A Aventura Liberal numa Ordem Patrimonialista. Revista USP, No. 17, 1993.

${ }^{28}$ FAORO, Raymundo. A Aventura Liberal numa Ordem Patrimonialista. Revista USP, No. 17, 1993, p. 17.

${ }^{29}$ PRADO JUNIOR, Caio. Formação do Brasil Contemporâneo: colônia. São Paulo, SP: Companhia das Letras, 2011, p. 353-354. 
Não se ignora as reformas trazidas pelos Administradores no Brasil Colônia, dentre as quais se destaca a Administração de Pombal com seu despotismo esclarecido. Na Administração da Justiça a chamada "lei da boa razão", que trazia critérios objetivos para extração de regras de direito para preencher omissões nas leis vigentes, gerou mais do que mera reforma na burocracia, mas a manifestação de uma nova perspectiva racionalista. ${ }^{30}$

No âmbito da Administração propriamente dita, foram contribuições de Pombal: a transferência do centro administrativo para o Rio de Janeiro enquanto centro do país; a consolidação da organização administrativa centralizada com a extinção das capitanias hereditárias; distribuição de suas atribuições entre auxiliares mediante instruções e normas; criação e transformação de comarcas e vilas; regulação do comércio; dentre outras. ${ }^{31}$

O objetivo da reforma, contudo, foi beneficiar a Metrópole e as elites locais: a aplicação da legislação na Colônia não buscava garantir os serviços mais elementares à população. Ao revés, em uma Administração de cunho feudal e patrimonialista, havia o Direito da elite agrária que não correspondia ao Direito da maior parte da população e existia apenas para proteger os interesses do governo real e manter o poder dos fazendeiros. ${ }^{32}$

A Administração de Pombal demarca apenas a mudança do patrimonialismo tradicional - originário e patriarcal com o estereótipo do cargo como título de nobreza - para o estamental - com a racionalização dos negócios públicos, separação "conceitual e jurídica", do patrimônio público do doméstico - assumindo a camada dirigente um caráter burocrático permitindo que o Estado absolutista se "preparar" mais para tutelar a economia. ${ }^{33}$

A tentativa de formação de uma burocracia profissionalizada, alheia às pressões e às influências, ignorou um aspecto típico da estrutura institucional no Brasil, a interpenetração entre a burocracia e as relações

30 SALDANHA, Nelson Nogueira. História das Idéias Políticas no Brasil. Brasília, DF: Senado Federal, 2001, p. 58.

31 VIANNA, Hélio. História do Brasil: Período Colonial, Monarquia e República. 12 ed. São Paulo, SP: Editora da Universidade de São Paulo, 1975, p. 307-310.

32 WOLKMER, Antônio Carlos. História do Direito no Brasil. $3^{\text {a }}$ ed. Rio de Janeiro, RJ: Forense, 2003, p. 48.

${ }^{33}$ AVELLAR, Hélio de Alcântara. História Administrativa do Brasil, Vol. 5. Rio de Janeiro, RJ: DASP, 1970, p. 98. 
sociais de parentesco, amizade, apadrinhamento e suborno ${ }^{34}$, de modo que as estruturas absolutistas na Administração Pública, não se emancipam sequer com a independência política do Brasil permanecendo a mesma máquina administrativa, com os mesmos "processos, privilégios e parasitas"; "costumes" e a "freguesia financeira". ${ }^{35}$

Isto porque, o patrimonialismo permanece atuante por "debaixo", "encoberto" por uma ordem burocrática-racional na Administração Pública e se desenvolvendo no quadro administrativo como resquício do caráter político assumido pela economia colonial. A independência marca a adoção da "máscara" do capitalismo liberal que falseia a "herança" do patrimonialismo português, que permanece nas instituições políticoadministrativas. ${ }^{36}$

Neste tocante, já sob a égide do Brasil República, esse é o contexto que encontra o Governo Vargas: uma Administração Pública marcada pela ineficiência, pelo patrimonialismo e pelo autoritarismo, que denotará sua preocupação com as questões do funcionalismo e importará na realização de reformas que busquem trazer maior economia e eficiência no serviço público e profissionalização e impessoalidade na função administrativa.

\section{REFORMAS ADMINISTRATIVAS NO GOVERNO VARGAS}

Inicia a Administração Pública Brasileira já sob o regime da República no século XX com o mesmo modelo oligárquico e patrimonialista, marcado pelo predomínio da corrupção, do nepotismo e da ineficiência na gestão estatal, em uma economia com baixo grau de competitividade e concentração da função pública em uma sociedade ainda eminentemente aristocrática ${ }^{37}$.

34 SCHWARTZ, Stuart B. Burocracia e sociedade no Brasil colonial. São Paulo, SP:

Editora Perspectiva, 1979, p. 251.

${ }^{35}$ BOMFIM, Manoel. A América Latina: males de origem. Rio de Janeiro, RJ: Centro

Edelstein de Pesquisas Sociais, 2008, p. 179.

${ }^{36}$ FAORO, Raymundo. A Aventura... Op. cit. p. 17.

${ }^{37}$ Assim como no Brasil Império, no primeiro período da República, enquanto os senhores de Terra e os grandes comerciantes se ocupavam da economia, ao Estamento burocrático ligado por laços de família ao patriarcado rural cabia dominar com relativa autonomia o Estado e a Política. BRESSER-PEREIRA, Luiz Carlos. Do Estado Patrimonial ao Gerencial. In: Afrânio Garcia; Ignacy Sachs; Jorge Wilheim; Paulo Sérgio de M.S. Pinheiro (Orgs.). Brasil: Um Século de Transformações. São Paulo, SP: Cia. das Letras, 2001, p. 222. 
Nas instituições administrativas, a burocracia estamental formada por agentes selecionados por critérios de confiança pessoal, permanece exercendo o munus publico finalisticamente direcionado aos seus interesses privados e não da coletividade, de forma autoritária e desvinculada de qualquer preocupação com a prestação eficiente dos serviços públicos ${ }^{38}$.

Não obstante, a ascensão do governo de Getúlio Vargas e a aceleração do processo de industrialização na década de 30 importará na tentativa de uma mudança deste modelo para um padrão burocrático denotado pelo formalismo exacerbado, a hierarquia e o controle rígido dos processos, buscando imprimir impessoalidade e eficácia na atuação administrativa.

A preocupação com o problema do funcionalismo já era observado ainda na plataforma política de 1930 onde explicitou a necessidade de economicidade - com redução de cargos - eficiência - mediante atribuição de garantias aos agentes que permitiria exigir maior rendimento das atividades - e de impessoalidade - com a criação de critérios na seleção e promoção dos agentes - algo que permeia, também, o discurso de posse de Getúlio Vargas. ${ }^{39}$

Neste tocante, as primeiras reformas buscando maior economia e eficiência da Administração foram decretos autorizando o ministro da Fazenda a delegar atribuições a diretores e chefes de serviço da Administração Fazendária a fim de reduzir o expediente ${ }^{40} \mathrm{e}$ a organização de uma Comissão Especial no Ministério da Fazenda para estabelecer padrões oficiais a serem adotados nos fornecimentos de materiais necessários a execução do serviço. ${ }^{41}$

Ademais, instituiu Comissão legislativa para reforma da legislação vigente, inclusive, os problemas da Administração ${ }^{42}$, dentre inúmeros atos legislativos expedidos entre 1930 e 1934 que ordenaram a organização e reorganização de repartições, criação e extinção de órgãos e cargos, transferência de órgãos para outros ministérios e providências

${ }^{38}$ HOLANDA, Sérgio Buarque de. Raízes do Brasil. 17ª ed. Rio de Janeiro, RJ: J. Olympio Editora, 1984, p. 105-107.

39 WAHRLICH, Beatriz M. de Souza. Reforma Administrativa na Era Vargas. Rio de Janeiro, RJ: Instituto de Documentação/Editora da FGV, 1983, p. 3/7.

${ }^{40}$ BRASIL. Decreto no 19.505 de 17 de Dezembro de 1930.

${ }^{41}$ BRASIL, Decreto no 19.512 de 20 de Dezembro de 1930.

${ }^{42}$ BRASIL, Decreto no 19.459 de 06 de Dezembro de 1930. 
análogas que marcaram a diretiva de reforma administrativa ${ }^{43}$.

Após a promulgação da Constituição de 1934, marcada pela ampliação da disciplina da Administração Pública em relação às cartas anteriores ${ }^{44}$, surgem reformas administrativas inicialmente concentradas na Administração de Pessoal, como a aprovação do primeiro plano federal de classificação de cargos, que institucionalizou o sistema do mérito, incorporado na próxima carta de 1937.45

Adotando a lei, como princípio geral, a formação de carreiras reorganizava os quadros e carreiras do funcionalismo civil federal, determinava a criação de Comissões de Eficiência e buscava superar a diversidade de vencimentos para cargos de igual categoria com a definição de padrões legais de vencimento para os funcionários públicos, além de definir regras de promoção e transferência dentre outros. ${ }^{46}$

Criou, também, o Conselho Federal do Serviço Público responsável pela implantação do sistema de mérito com concursos para ingresso na carreira dotados de imparcialidade e objetividade do julgamento mediante desidentificação das provas e uso de provas objetivas de múltipla escolha, o regulamento de promoções com estabelecimento de sistemas de coeficientes numéricos. ${ }^{47}$

Foi responsável, ainda, pelos estudos preliminares para elaboração do Estatuto dos funcionários, a revisão das tabelas orçamentárias proposta pelos ministérios, a classificação por ordem de antiguidade conforme a referida lei, a instituição do serviço de pessoal, apuração de funcionários que ocupavam interinamente os cargos públicos e orientação para adoção de medidas, relatório sobre a criação do Instituto Nacional de Previdência

${ }^{43}$ WAHRLICH, Beatriz M. de Souza. Reforma Administrativa na Era Vargas. Rio de Janeiro, RJ: Instituto de Documentação/Editora da FGV, 1983, p. 131-136.

${ }^{44}$ Enquanto a Constituição do Império de 1824 nada dispunha e a Constituição de 1891 apenas continua duas normas acerca sobre a Administração Pública, com a Constituição de 1934 se ensaiou, ainda que de forma tímida, uma tendência centralizadora e ampliativa da matéria administrativa, incluindo com a presença de um título dedicado aos agentes públicos. MOREIRA NETO, Diogo de Figueiredo.

Apontamentos sobre a Reforma Administrativa: Emenda Constitucional no 19, de 4 de junho de 1998. Rio de Janeiro, RJ: Renovar, 1999, p. 11.

${ }^{45}$ BRASIL, Constituição de 1936. Artigo 67.

${ }^{46}$ BRASIL, Lei no 284 de 28 de Outubro de 1936.

${ }^{47}$ WAHRLICH, Beatriz M. de Souza. Reforma Administrativa na Era Vargas. Rio de Janeiro, RJ: Instituto de Documentação/Editora da FGV, 1983, p. 131-136.

2 JOURNAL OF INSTITUTIONAL STUDIES 1 (2016) 
dentre outros. ${ }^{48}$

Houve, no mesmo período, a criação da Comissão Central de Compras, que buscou centralizar as compras e os fornecimentos de artigos destinados à execução dos serviços federais ${ }^{49}$, bem como a Comissão Permanente de Padronização, criada para ser responsável pelo estudo e fixação dos padrões a ser obedecido por todo material de escritório que tenha sido adquirido para uso das repartições ou serviços federais. ${ }^{50}$

Foram realizadas, ainda, reformas em distintos órgãos da Administração, como no Ministério da Educação e da Saúde ${ }^{51}$, que correspondiam, além de uma reforma propriamente dita, a um plano geral de ação governamental na educação e saúde pública, tendo culminado na promulgação da lei que organizou a Universidade do Brasil ${ }^{52}$ e na criação de um órgão complementar: a Seção de Segurança Nacional do respectivo Ministério. ${ }^{53}$

Note que tal órgão de Segurança Nacional, que também foi instituído em cada um dos ministérios ${ }^{54}$, tinha como atribuição determinar as medidas que deveriam ser adotadas pelos respectivos ministérios para cooperar com a Segurança Nacional, além de coordenar as atividades das instituições públicas ou particulares relativas, para fim de serem convenientemente utilizadas tendo em vista aquele objetivo.

De igual forma, foram realizadas reformas nos órgãos integrantes da Presidência da República ou diretamente a eles subordinados, como o Conselho de Defesa Nacional ${ }^{55}$, o Ministério do Trabalho, Indústria e Comércio, da Agricultura, da Viação e Obras Públicas dentre outros, que demonstram a preocupação do Governo Vargas com a reforma do aparato administrativo de forma a garantir o programa político social.

No ciclo de reformas administrativas observadas pelo Governo Vargas entre a década de 1930 e 1940, é clara a adoção do modelo prescrito das teorias administrativas tanto da experiência europeia quanto da americana com uma reforma modernizadora que tentava

${ }^{48}$ WAHRLICH, Beatriz M. de Souza. Reforma Administrativa na Era Vargas. Rio de Janeiro, RJ: Instituto de Documentação/Editora da FGV, 1983, p. 137-150.

${ }^{49}$ BRASIL, Decreto no 19.587 de 14 de Janeiro de 1931.

${ }^{50}$ BRASIL, Decreto no 562 de 31 de Dezembro de 1935.

${ }^{51}$ BRASIL, Lei no 378 de 13 de Janeiro de 1937.

52 BRASIL, Lei no 052 de 5 de Julho de 1937

${ }^{53}$ BRASIL, Decreto no 2.036 de 11 de Outubro de 1937.

${ }^{54}$ BRASIL, Decreto oㅜ 23.873 de 15 de Fevereiro de 1934. Artigo 3ㅜ.

${ }^{55}$ BRASIL, Decreto no 23.873 de 15 de Fevereiro de 1934. 
trazer paradigmas criados pelos modelos taylorista, fayoliano e weberiano nas atividades exercidas pela Administração Pública em geral..$^{56}$

Demonstra-se a busca por soluções na melhoria, por exemplo, do serviço público no modelo comparado, com a Missão de Estudos no Estrangeiro $^{57}$, onde o Governo promoveu o intercâmbio de técnicos e funcionários administrativos federais brasileiros para aperfeiçoamento no exterior, principalmente para universidades estrangeiras e de forma majoritária para instituições nos Estados Unidos da América. ${ }^{58}$

Tal concepção parte-se da premissa que o agente público em ação "não mais agiria como ser individual e o resultado de suas atividades seria transmutado de si e imputado ao ente coletivo", como se de alguma forma se desprendesse da ação volitiva individual e corporifica-se a instituição "como se essa tivesse vida e realizasse suas próprias escolhas em direção ao bem-estar da população". .9

Porém, tal compreensão baseia-se em um modelo de racionalização burocrática do Estado oriunda de uma dominação racional-legal que não é típica de toda organização estatal, mas resultado de um processo histórico de certo tipo de Direito e de dada forma estatal - o Estado Moderno da Europa Continental -, marcados por uma burocratização administrativa com alto grau de especialização, racionalidade e objetividade. ${ }^{60}$

Algo que se distancia da trajetória da América latina, cujo traço comum é o surgimento de Estados Corporativistas, Legalistas e Centralizados, marcados pela personalização do poder no âmbito local com tendência a prossecução dos interesses pessoais - parentes, amigos e clientes - do que o conceito de "bem comum", sendo a evolução administrativa caracterizada por estar "imersa em círculos viciosos" de

${ }^{56}$ WAHRLICH, Beatriz M. de Souza. Reforma Administrativa Federal Brasileira:

Passado e Presente. Revista de Administração Pública, Vol. 8, 2, 1974.

${ }^{57}$ BRASIL, Decreto-Lei no 776 de 7 de Outubro de 1938.

${ }^{58}$ RABELO, Fernanda Lima. O DASP e o combate à ineficiência nos serviços públicos: a atuação de uma elite técnica na formação do funcionalismo público no Estado Novo (1937-1945). Revista Brasileira de História \& Ciências Sociais, Vol. 3, 6, 2011, p. 135.

${ }^{59}$ ALVIM, Joaquim Leonel de Rezende; NUNES, Tiago de García. O jeitinho brasileiro, o homem cordial e a impessoalidade administrativa: encontros e desencontros na navegação da máquina pública brasileira. Anais do II seminário dos Estudantes de Pós-graduação em Ciências Sociais do RJ. Rio de Janeiro, RJ: Editora ANPG, 2012, p. 17.

${ }^{60}$ WEBER, Max. O Que é Burocracia? Brasília, DF: Conselho Federal de Administração, s/a, p. 29-32/39. 
autoritarismo. ${ }^{61}$

Por esta razão, observa-se uma incongruência entre a teoria e a práxis do Direito Administrativo nesses países, uma vez que apesar da consagração dos princípios democráticos básicos e das garantias processuais do administrado em face do Estado, há um "déficit normativo e falta de cumprimento das normas existentes", com falta de leis adequadas, agentes capacitados para sua aplicação, corrupção e falta de participação e controle social. ${ }^{62}$

Exemplo disto foi o sistema adotado pela lei de classificação de cargos, de chefia em comissão conduziu a uma generalização e adoção indiscriminada do provimento dos cargos de direção, gerando males como a seleção por critérios não vinculados à qualidade do desempenho, ensejou o comodismo, estimulou a transigência e permitiu a manutenção de ocupantes temerosos por questão de prestígio ou financeira que não desejam perder tais cargos. ${ }^{63}$

As disfunções desse modelo foram observáveis na burocracia federal brasileira já na década de 1940, pela concentração nos aspectos formais da organização, negligenciando o estudo dos processos de modificação por padrões informais, a preocupação dominante com a racionalidade e eficiência dos meios e não com a plena realização dos fins, a insuficiência de flexibilidade para reagir às transformações situacionais e na deformação profissional. ${ }^{64}$

A tentativa de adoção do modelo burocrático na década de 1930 e 40, buscando-se um processo de racionalização da atividade administrativa, não foi capaz de superar o patrimonialismo contra o qual a Administração Pública burocrática se instalara, que "embora em processo de transformação, mantinha ainda sua própria força no quadro político brasileiro. O coronelismo dava lugar ao clientelismo e ao fisiologismo" ${ }^{65}$

${ }^{61}$ MENDEZ, José Luiz. Estudio Introductorio. In: B. Guy Peters. La Política de La

Burocracia. Trad. Eduardo L. Suárez Galindo. México: Fondo de cultura económica, 1999, p. 15.

${ }^{62}$ BERNHARD, Regina. El Derecho Administrativo en Países de América del Sur: ¿Coincide la teoria con la realidad? Comparación y evaluación de diferentes sistemas.

Anuario de Derecho Constitucional Latino-Americano, Año 14, 2008.

63 WAHRLICH, Beatriz M. de Souza. Reforma Administrativa na Era Vargas. Rio de Janeiro, RJ: Instituto de Documentação/Editora da FGV, 1983, p. 108-109.

${ }^{64}$ WAHRLICH, Beatriz M. de Souza. Reforma Administrativa na Era Vargas. Rio de Janeiro, RJ: Instituto de Documentação/Editora da FGV, 1983, p. 296.

${ }^{65}$ BRESSER-PEREIRA, Luiz Carlos. Plano Diretor da Reforma do Aparelho do Estado. Brasília, DF: Câmara da Reforma do Estado, 1995, p. 19. 
Ademais, encontrou limite a cultura da Administração Pública Brasileira, nas tradições econômico-sociais brasileiras do Estado Patrimonialista - da carreira pública como forma de satisfação dos interesses privados e da ação administrativa não como atendimento das necessidades coletivas, mas mecanismo de manipulação as clientelas eleitorais destinado a perpetuar privilégios da classe dominante. ${ }^{66}$

Com as reformas administrativas de Vargas não se partiu da realidade político-social do Estado Brasileiro, mas se realizou o mero transplante de teorias e práticas desenvolvidas em outro contexto político-social - no caso o Estados Unidos - em um esforço de equacionar os problemas da Administração Brasileira sem considerar os traços de patrimonialismo e autoritarismo das estruturas e burocracia administrativas pátria.

Sob pressões populistas-clientelistas instituiu-se um padrão persistente até os dias atuais onde os altos escalões sob influxo da reforma se profissionalizaram os escalões inferiores - inclusive os recentes órgãos encarregados dos serviços de saúde e de assistência social então criados - "foram deixados ao critério clientelista de recrutamento de pessoal por indicação e à manipulação populista dos recursos públicos." ${ }^{67}$

Houve uma rejeição do padrão weberiano pelas condições ecológicas sentidas através do sistema de mérito de ingresso na Administração Federal, minado pelo amplo contingente de servidores não abrangidos pela norma constitucional, o caráter temporário das respectivas funções, o critério de confiança pessoal que presidia as respectivas nomeações de dirigentes de todos os níveis. ${ }^{68}$

A tentativa de orientar o funcionamento da Administração Pública por critérios weberianos de racionalidade, tecnicidade, mérito e impessoalidade não encontra respaldo ecológico que permita a utilização da burocracia como instrumento de eficiência, resultando antes em uma burocracia do "tipo sala", onde não se ignora a racionalidade como critério administrativo, porém, esta não é orientada por tal valor. ${ }^{69}$

Ademais, o discurso de valorização da cientificidade e da

${ }^{66}$ JAGUARIBE, Hélio. O Nacionalismo na Atualidade Brasileira. Rio de Janeiro, RJ: Ministério da Educação e Cultura, Instituto Superior de Estudos Brasileiros, 1958, p. 41.

${ }^{67}$ MARTINS, Luciano. Reforma da Administração Pública e Cultura Política no

Brasil: uma visão geral. Brasília, DF: Escola Nacional de Administração Pública, 1997, p. 17.

${ }^{68}$ OLIVEIRA, Gercina Alves de. A Burocracia Weberiana e a Administração Federal Brasileira. Revista de Administração Pública, Vol. 4, 2, 1970.

${ }^{69}$ OLIVEIRA, Gercina Alves de. A Burocracia Weberiana e a Administração Federal Brasileira. Revista de Administração Pública, Vol. 4, 2, 1970, p. 68. 
meritocracia, em detrimento das decisões e indicações políticas, entrava em conflito com o próprio governo autoritário do Estado Novo, de forma que as normas editadas pela elite burocrática com os funcionários públicos federais não ocorria, pois na prática encontravam limites nas relações sociais e políticas existentes. ${ }^{70}$

Por efeito, as reformas administrativas da Era Vargas não corresponderam à superação das mazelas patrimonialista e autoritária da Administração Pública, mas importou na mera criação de um Estado administrativo, que buscava a formação de um aparato moderno e a adoção de uma técnica racional-legal, que "não resistia às pressões clientelísticas, e que, para impor o seu poder de dominação, usava, sem medo, estratagemas informais". ${ }^{71}$

Isto ocorria, precipuamente, através da criação de uma estrutura administrativa paralela e de inúmeros cargos "extranumerários" para atender aos crescentes pedidos de emprego, com a criação de inúmeros entes da Administração Pública Indireta ou Autárquica, que davam maior espaço à utilização política e a contratação de agentes sem concurso público, mas por indicações pessoais, de forma que tal classe alcançou número superior ao de estatutários. ${ }^{72}$

Portanto, embora o discurso - modelo racional-legal weberiano - seja compatível com a proposta modernizante do período revolucionário, uma vez iniciado o Governo de Vargas, as alianças pré-revolucionárias, a cooptação pelas oligarquias e a excessiva centralização dentre outros são fatores que conduziram a um distanciamento do modelo para algo mais compatível com o caráter do Estado Brasileiro. ${ }^{73}$

A representação ideológica da burocracia ideal weberiana com fins utilitários e métodos racionais serviu para justificar as práticas internas da Administração Pública. Porém, a defasagem entre o modelo formal e as sustentações e articulações sócio-políticas que resultaram em um distanciamento entre a teoria e a práxis na atividade administrativa, entre

\footnotetext{
${ }^{70}$ RABELO, Fernanda Lima. O DASP e o combate à ineficiência nos serviços públicos: a atuação de uma elite técnica na formação do funcionalismo público no Estado Novo (1937-1945). Revista Brasileira de História \& Ciências Sociais, Vol. 3, 6, 2011, p. 140. ${ }^{71}$ GOUVÊA, Gilda Portugal. Burocracia e Elites Burocráticas no Brasil. São Paulo, SP: Paulicéia, 1994, p. 58.

72 GOUVÊA, Gilda Portugal. Burocracia e Elites Burocráticas no Brasil. São Paulo, SP: Paulicéia, 1994, p. 73.

${ }^{73}$ FERRARI, Levi Bucalem. Burocratas \& Burocracias. São Paulo, SP: Editora Semente, 1981, p. 174.
} 
as tentativas de reforma e a defasagem nas suas propostas. ${ }^{74}$

Não encontrando no sistema brasileiro os elementos adequados para organização e funcionamento do modelo weberiano, a burocracia federal tornou-se ante um "instrumento de dominação política do Governo Totalitário de Getúlio Vargas" que através dela permitiu a implementação da sua plataforma política, garantindo condições básicas ao desenvolvimento da nação. ${ }^{75}$

Iniciou-se, portanto, o projeto de governo nacionaldesenvolvimentista da Era Vargas, que era marcado por um ativo intervencionismo estatal e pelo apoio à industrialização substitutiva de importações característica de uma Administração Pública Burocrática, com afirmação de princípios como centralização administrativa, controle hierárquico e processos rígidos. ${ }^{76}$

Torna-se a burocracia moderna brasileira, a partir da revolução de 1930, parcela da nova coalizão política ou bloco de poder que se forma dentro de uma recém-formada tecnoestrutura estatal, com agentes que embora com formações teóricas e ideologias políticas diferentes, "partilhavam as ideias nacionalistas e desenvolvimentistas dominantes na sociedade brasileira" e atuaram com fins a sua realização. ${ }^{77}$

Neste tocante, o aparato administrativo exerceu papel na adoção e implementação de medidas garantidoras de realização do projeto político desenvolvimentista do Governo Vargas, apontando-se como órgão que exerceu papel importante na centralização e controle da Administração Pública, com vista a tais fins, o Departamento Administrativo do Serviço criado durante o Estado Novo.

\section{A CRiação do DASP E O SeU Papel no GoVerno VARGAS}

Com a ascensão do Estado Novo, volta-se o Governo Vargas a

${ }^{74}$ FERRARI, Levi Bucalem. Burocratas \& Burocracias. São Paulo, SP: Editora Semente, 1981, p. 175-176.

${ }^{75}$ OLIVEIRA, Gercina Alves de. A Burocracia Weberiana e a Administração Federal

Brasileira. Revista de Administração Pública, Vol. 4, 2, 1970, p. 69.

${ }^{76}$ BRESSER-PEREIRA, Luiz Carlos. Crise Econômica e Reforma do Estado no Brasil: para uma nova interpretação da América Latina. São Paulo, SP: Editora 34, 1996, p.

$36 / 273$

77 BRESSER-PEREIRA, Luiz Carlos. Burocracia Pública e Classes Dirigentes no Brasil.

Revista de Sociologia Política, No. 28, 2007, p. 49. 
empreender novas reformas administrativas, justificando no próprio discurso de instituição do novo Estado o não ajustamento do aparelho governamental às exigências da vida nacional, inibindo a sua expansão, em razão com pouco rendimento e eficiência, decorrentes da influência dos interesses personalistas e das composições políticas eventuais. ${ }^{78}$

Para garantir o aperfeiçoamento governamental e a elaboração orçamentária é criado com fulcro na Constituição de $1937^{79}$, porém, com ampliação de suas atribuições, o Departamento Administrativo do Serviço responsável por organizar a proposta e fiscalizar a execução do orçamento, selecionar os candidatos aos cargos públicos federais, examinar os projetos de lei submetido a sanção, inspecionar os serviços dentre outros. ${ }^{80}$

Em sua organização, o DASP era formado por uma presidência, um Conselho Deliberativo e cinco Divisões - Divisão de Organização e Coordenação, Divisão do Funcionário Público, Divisão do Extranumerário, Divisão de Seleção e Aperfeiçoamento e Divisão de Material - além dos serviços auxiliares - com funções de Comunicações, mecanografia, Material e Publicidade dentre outros.

Inicialmente, as atribuições de elaboração e fiscalização da execução do orçamento eram realizadas pelo Ministério da Fazenda com a assistência de um delegado do DASP 81 , até a constituição de uma Comissão de Orçamento no respectivo ministério sob a presidência do presidente do $\mathrm{DASP}^{82}$ e, por fim, a instalação de uma Divisão de

${ }^{78}$ WAHRLICH, Beatriz M. de Souza. Reforma Administrativa na Era Vargas. Rio de Janeiro, RJ: Instituto de Documentação/Editora da FGV, 1983, p. 235.

${ }^{79}$ BRASIL, Constituição dos Estados Unidos do Brasil, de 10 de Novembro de 1937. Artigo 67: "Haverá junto à Presidência da República, organizado por decreto do Presidente, um Departamento Administrativo com as seguintes atribuições: a) o estudo pormenorizado das repartições, departamentos e estabelecimentos públicos, com o fim de determinar, do ponto de vista da economia e eficiência, as modificações a serem feitas na organização dos serviços públicos, sua distribuição e agrupamento, dotações orçamentárias, condições e processos de trabalho, relações de uns com os outros e com o público; b) organizar anualmente, de acordo com as instruções do Presidente da República, a proposta orçamentária a ser enviada por este à Câmara dos Deputados; c) fiscalizar, por delegação do Presidente da República e na conformidade das suas instruções, a execução orçamentária.

80 BRASIL, Decreto-Lei no 579 de 30 de Julho de 1938. Artigo $2^{\circ}$.

${ }^{81}$ BRASIL, Decreto-Lei no 579 de 30 de Julho de 1938. Artigo 3o Parágrafo Único.

${ }^{82}$ BRASIL, Decreto-Lei no 2.026 de 21 de Fevereiro de 1940. 
Orçamento no DASP ${ }^{83}$ responsável pela matéria.

Ademais, havia em cada ministério uma Comissão de Eficiência, subordinada ao DASP responsável por estudar a organização de cada serviço, propor ao ministro de Estado as alterações que julgasse conveniente, opinar sobre transferências, remoções e permutas, opinar na proposta de admissão, recondução e dispensa de pessoal extranumerário, dentre outras. ${ }^{84}$

Sucessivas ampliações foram realizadas nas atribuições do DASP, permitindo a fiscalização de projetos e contratos, estabelecimento de normas e padrões para a construção e adoção de qualquer medida julgada conveniente relativa aos edifícios destinados serviços públicos civis, que não sofriam qualquer construção, remodelação ou adaptação sem autorização do Chefe do Executivo. ${ }^{85}$

Uma das unidades do Serviço Auxiliar do DASP - o Serviço de Publicidade - foi transformado em Serviço de Documentação, sendo incumbido da guarda dos textos, fornecimento de noticiário de suas atividades para o Departamento de Imprensa e propaganda, bem como a promoção da divulgação de trabalhos de interesse da Administração Pública. ${ }^{86}$

Houve a criação de órgãos colegiados junto ao DASP: o Conselho de Administração de Material, responsável por promover a coordenação e eficiência dos órgãos sob tal atribuição ${ }^{87}$ e o Conselho de Administração de Pessoal, com função análoga e distintos divisões, sendo os chefes ou diretores dos órgãos designados pelo presidente do DASP. ${ }^{88}$

Com a ampliação dos objetivos iniciais do DASP, houve a absorção tanto do Conselho Federal do Serviço Público como da Comissão Permanente Padronização, tornando-o mais abrangente que o modelo comparado ao qual se baseou - Bureau de Orçamento do Estados Unidos da América - e a teoria ao qual se fundava do departamento de administração geral de Willoughby. ${ }^{89}$

Outras inúmeras reformas demonstram a tendência governamental de fortalecer o DASP assumindo amplas funções fiscalizadoras, normativas e executivas ciclo interrompido apenas com a queda de

\footnotetext{
83 BRASIL, Decreto no 7.416 de 26 de Março de 1945.

${ }^{84}$ BRASIL, Decreto-Lei no 579 de 30 de Julho de 1938. Artigo 17.

${ }^{85}$ BRASIL, Decreto-Lei no 1.720 de 30 de Outubro de 1939. Artigo $1^{\circ}$.

${ }^{86}$ BRASIL, Decreto-Lei no 2.039 de 27 de Fevereiro de 1940.

${ }^{87}$ BRASIL, Decreto-Lei no 5.715 de 31 de Julho de 1943.

88 BRASIL, Decreto-Lei no 5.937 de 28 de Outubro de 1943.

${ }^{99}$ WAHRLICH, Beatriz M. de Souza. Reforma Administrativa na Era Vargas. Rio de Janeiro, RJ: Instituto de Documentação/Editora da FGV, 1983, p. 315.
} 
Getúlio Vargas ${ }^{90}$, quando "faltou ao processo reformista o respaldo do regime autoritário em que fora concebido e implantado, o sistema entrou em processo de entropia, do qual jamais se recuperou totalmente".$^{91}$

Inserido em um modelo onde o Poder Executivo concentrava funções legiferantes e resultava em maior fiscalização administrativa, maior centralização e mais ampla função de staff, a tendência do DASP era de crescimento e de absorção de funções fiscalizadoras, legislativas e executivas, o que acabava denotando com a centralização de toda atividade uma feição de órgão autoritário. ${ }^{92}$

Ademais, com um insulamento burocrático, retira-se o DASP enquanto órgão crucial da esfera do aparato administrativo tradicional, do espaço político governado pelo Congresso e pelos partidos, resguardando aquela organização contra as referidas influências, garantindo que se ligue apenas ao projeto político desenvolvimentista do governo.

Isto não importou em superação material das questões administrativas brasileiras propostas pelas reformas. Com as elites profissionais modernizantes não se cria um domínio do público, superando as instituições políticas clientelistas, mas o seu distanciamento da res publica com a intensificação dos anéis burocráticos com a ligação da burocracia com a elite econômica agora através da técnica.

A tentativa de adoção de um modelo weberiano, para utilização do aparato administrativo como instrumento de ação do governo de Vargas, indispensável ao desenvolvimento conforme os interesses nacionais e a modernização administrativa, fez com que a tecnoburocracia se apegasse à forma, à lei e as técnicas, utilizando o conhecimento técnico especializado não como meio, mas fim de perpetuação no poder. ${ }^{93}$

Ademais, essa autoconservação do grupo com status e parcela de poder dentro da sociedade corroborou para que houvesse, mesmo diante de um Estado Democrático, penetração de influências político-partidárias na burocracia subordinando sua ação aos interesses políticos e econômicos dos grupos, nem sempre condizentes com os interesses do

${ }^{90}$ WAHRLICH, Beatriz M. de Souza. Reforma Administrativa na Era Vargas. Rio de Janeiro, RJ: Instituto de Documentação/Editora da FGV, 1983, p. 257.

${ }^{91}$ WAHRLICH, Beatriz M. de Souza. Reforma Administrativa Federal Brasileira:

Passado e Presente. Revista de Administração Pública, Vol. 8, 2, 1974, p. 29.

${ }_{92}$ WAHRLICH, Beatriz M. de Souza. Reforma Administrativa na Era Vargas. Rio de Janeiro, RJ: Instituto de Documentação/Editora da FGV, 1983, p. 261-262/839.

${ }_{93}$ OLIVEIRA, Gercina Alves de. A Burocracia Weberiana e a Administração Federal Brasileira. Revista de Administração Pública, Vol. 4, 2, 1970, p. 69-70. 
sistema social como um todo. ${ }^{94}$

Ainda sob a perspectiva weberiana, observa-se a continuidade da característica histórica predominante do Estado Brasileiro de sua dimensão patrimonial, que mesmo com a profissionalização da burocracia, conserva o antigo estamento burocrático com apropriação da função pública para interesse privado e a subordinação e a dependência ao poder central. ${ }^{95}$

Com a autonomia e o insulamento do aparato administrativo como forma de proteção do núcleo técnico do Estado, permitindo a tomada de decisões e a implementação de projetos à revelia das interferências e disputas políticas, conduziu-se a arbitrariedades, sendo usualmente identificado tal fenômeno com períodos autoritários de governo, como ocorrido na Ditadura Militar com o Serviço Nacional de Informações. ${ }^{96}$

É comum se associar as reformas administrativas do Governo Vargas com as propostas pela Ditadura Militar, pois se ligam ao projeto político desenvolvimentista do Estado como indutor do crescimento econômico, sendo que o atuação do ente público como ator econômico exige a organização da máquina administrativa e, portanto, um aparato administrativo capaz de concretizar aqueles fins políticos. ${ }^{97}$

Ligam-se à própria manutenção do governo autoritário, pois a ascensão do Estado Novo e a necessidade de fortalecimento das Forças Armadas exigia uma reformulação do sistema de relação entre Estado e Sociedade e resultou na criação de uma estrutura administrativa rigidamente hierarquizada com características corporativistas que se apoiava na atuação do DASP nos referidos Estados. ${ }^{98}$

O DASP possuía ramificação em cada um dos Estados com a função de assessorar os interventores nas decisões técnicas, que importava na submissão dos interventores aos respectivos departamentos que atuavam como legislativos estaduais e que permitia, mediante a articulação entre o DASP e as Interventorias, o controle absoluto pelo Poder Executivo

${ }^{94}$ OLIVEIRA, Gercina Alves de. A Burocracia Weberiana e a Administração Federal Brasileira. Revista de Administração Pública, Vol. 4, 2, 1970, p. 70.

${ }_{95}^{5}$ SCHWARTZMAN, Simon. Bases do Autoritarismo Brasileiro. 4 ed. Rio de Janeiro, RJ: Publit Soluções Editoriais, 2007, p. 11-12.

${ }^{96}$ OLIVEIRA, Sonale Diane Pastro. A Ditadura Militar e o insulamento burocrático: 0 SNI, um estudo de caso. Em Tempo de Histórias, no 20, 2012, p. 38.

${ }^{97}$ OLIVEIRA, Clarice Gomes de. O Servidor Público Brasileiro: Uma Tipologia da Burocracia. Revista do Serviço Público, Vol. 58, 3, 2007.

98 GARCIA, Nelson Jahr. O Estado Novo, Ideologia e Propaganda Política: a legitimação do Estado autoritário perante as classes subalternas. São Paulo, SP: Edições Loyola, 1982, p. 62. 
Federal dos Estados, reduzidos a simples divisões administrativas. ${ }^{99}$

Tais Departamentos Administrativos ${ }^{100}$, chamados "Daspinhos", se reportavam diretamente à matriz federal e desempenhavam verdadeira função de fiscalização nos interventores e, portanto, constituíam uma linha de "transmissão da cadeia de centralização", exercendo além do papel de corpo legislativo, a atividade de supervisão das atividades dos interventores e dos prefeitos, das leis e decretos, inclusive, do orçamento.

Os ditos "daspinhos" são peças mestras do sistema, que atuam com "sucesso como peso e controle sobre o Interventor", uma vez que através desses departamentos administrativo subordinados ao DASP o interventor fica subordinado à política federal, agindo como se fosse o "coordenador político do estado, sob as instruções do próprio Vargas". ${ }^{101}$

Insere-se o DASP, portanto, como aparato estatal de um modelo de centralização das funções no Poder Executivo, de concentração no nível federal da tomada de decisões antes partilhadas com os estados, cuja ideologia política recupera práticas autoritárias que pertencem à tradição brasileira, além de incorporar outras modernas, como o uso da propaganda e da educação na sua adaptação à nova realidade social. ${ }^{102}$

Representava a cabeça racional-legal ligada ao intervencionismo e autoritário do Estado Novo, cujo insulamento burocrático não impedia que o órgão respondesse às contingências do Governo Vargas "distribuindo as benesses ou sanções de acordo com as exigências do jogo político e dando vazão - conforme o interesse - aos usos clientelísticos do Estado (a partir do Estado)". ${ }^{103}$

Ademais, com o suposto isolamento da burocracia contra a influência dos interesses particularistas da sociedade, se impedia o controle público das decisões administrativas, o que também favorecia o corporativismo, de forma que insulamento e corporativismo, segundo aponta a doutrina, transferiram para o governo federal "quase todos os recursos para o

${ }^{99}$ GARCIA, Nelson Jahr. O Estado Novo, Ideologia e Propaganda Política: a legitimação do Estado autoritário perante as classes subalternas. São Paulo, SP: Edições Loyola, 1982, p. 63.

${ }^{100}$ BRASIL, Decreto-Lei no 1.202 de 8 de Abril de 1939.

${ }^{101}$ LOEWENSTEIN, Karl. Brazil under Vargas. New York, NY: The Macmillan Co., 1942, p. 43-44.

102 OLIVEIRA, Lúcia Lippi; VELLOSO, Mônica Pimenta; GOMES, Angela Maria de Castro. Estado Novo: Ideologia e Poder. Rio de Janeiro, RJ: Zahar Editores, 1982, p. 10. ${ }^{103}$ BARIANI, Edilson. DASP: Entre a Norma e o Fato. In: Christina W. Andrews; Edilson Bariani (Orgs.). Administração pública no Brasil: breve história política. São Paulo, SP: Editora Unifesp, 2010, p. 10. 
exercício do clientelismo". ${ }^{104}$

Assim, o DASP nasce sob o "fardos do autoritarismo e do clientelismo como os germes dessa cultura política", além do patrimonialismo típica mazela da sociedade brasileira, pois não "há cordão de isolamento que "proteja" tão implacavelmente o Estado do ambiente social" impedindo o surgimento de interesses privados e particularistas sobre os seus órgãos. ${ }^{105}$

Atua dentro de um plano de reordenamento institucional onde principais decisões relativas às políticas dependiam de articulações e acordos efetuados dentro da alta burocracia estatal, que marcada por sua centralização e fortalecimento, resultou na instauração de um monopólio burocrático sobre as decisões políticas e a implementação das políticas governamentais. ${ }^{106}$

Neste tocante, a criação do DASP exteriorizou a formalização do crescente poder político da burocracia pública no Brasil uma vez que atuava como elemento de legitimação das ações tomadas por Vargas justificando os profissionais as decisões já tomadas - ou de formação dos planos adotados - por vezes o Governo se valia dos conselhos e sugestões dos técnicos ou dos intelectuais públicos do referido órgão. ${ }^{107}$

Os aparatos burocráticos atuam na centralização com fins de garantir o controle interno do próprio Estado, de forma que o DASP estendeu o controle burocrático e ideológico sobre os agentes, os meios materiais, organizacionais e orçamentais, além dos projetos de lei submetidos ao chefe do Executivo, função estendida também ao assessoramento burocrático no âmbito Estadual, ampliando seu papel centralizador. ${ }^{108}$

Isto se reforça pelo fato que o mecanismo hierárquico de decisão formado pelo eixo DASP resultou em uma homogeneização

${ }^{104}$ BARIANI, Edilson. DASP: Entre a Norma e o Fato. In: Christina W. Andrews; Edilson Bariani (Orgs.). Administração pública no Brasil: breve história política. São Paulo, SP: Editora Unifesp, 2010, p. 10

${ }^{105}$ BARIANI, Edilson. DASP: Entre a Norma e o Fato. In: Christina W. Andrews; Edilson Bariani (Orgs.). Administração pública no Brasil: breve história política. São Paulo, SP: Editora Unifesp, 2010, p. 11

${ }^{106}$ DINIZ, Eliz. Engenharia institucional e políticas públicas: dos conselhos técnicos às câmaras setoriais. In: Dulce Chaves Pandolfi (Org.). Repensando o Estado Novo. Rio de Janeiro, RJ: Editora FGV, 1999, p. 27.

${ }^{107}$ BRESSER-PEREIRA, Luiz Carlos. Burocracia Pública e Classes Dirigentes no Brasil. Revista de Sociologia Política, No. 28, 2007, p. 15.

108 FERRARI, Levi Bucalem. Burocratas \& Burocracias. São Paulo, SP: Editora Semente, 1981, p. 178.

2 JOURNAL OF INSTITUTIONAL STUDIES 1 (2016) 
organizacional e normativa entre as Administrações Públicas Estaduais e Federais, de forma que chegou, inclusive, a exigir que os projetos de estatutos para os agentes estaduais fossem encaminhados ao DASP onde receberia as alterações que julgasse necessárias. ${ }^{109}$

Note, portanto, que a nacionalização e a burocratização do processo decisório, com epicentro no DASP, apresenta-se como face de um processo de centralização e de concentração do Poder do Estado, onde a ideologia autoritária fornecia "os valores legitimadores do novo modelo, ressaltando o papel integrador do Estado forte e, sobretudo, a supremacia da técnica em relação à política" nos negócios públicos. ${ }^{110}$

Isto não significou a produção de um Estado neutro, imparcial, equidistante dos conflitos e "comprometido com o interesse público, enfatizado pelo discurso ideológico, mas uma articulação entre o mundo dos interesses e a esfera estatal pela institucionalização da estrutura corporativa" com incorporação dos "atores emergentes", a saber, trabalhadores urbanos e empresários industriais no sistema político. ${ }^{111}$

Ao contrário, com a queda do Estado Novo preservou-se o arcabouço institucional do governo, na tendência de um Executivo forte com controle do processo decisório pela alta burocracia e papel secundário da instância parlamentar no processo de formação de políticas enclausuradas no interior daquela, com a consolidação da tendência da formação de arenas de negociação entre elites dos setores público e público. ${ }^{112}$

Corroborando com o entendimento, a trajetória da Administração Pública no Brasil é marcada pela identificação do interesse público com os interesses privados - como restava nítido no período Colonial - ou confundia com os interesses do Estado - como usualmente ocorria no Império - do que propriamente com o interesse público tido como as

109 BRASIL, Decreto-Lei no 3.074 de 22 de Fevereiro de 1941.

${ }^{110}$ DINIZ, Eliz. Engenharia institucional e políticas públicas: dos conselhos técnicos às câmaras setoriais. In: Dulce Chaves Pandolfi (Org.). Repensando o Estado Novo. Rio de Janeiro, RJ: Editora FGV, 1999, p. 27-28.

${ }^{111}$ DINIZ, Eliz. Engenharia institucional e políticas públicas: dos conselhos técnicos às câmaras setoriais. In: Dulce Chaves Pandolfi (Org.). Repensando o Estado Novo. Rio de Janeiro, RJ: Editora FGV, 1999, p. 28.

112 DINIZ, Eliz. Engenharia institucional e políticas públicas: dos conselhos técnicos às câmaras setoriais. In: Dulce Chaves Pandolfi (Org.). Repensando o Estado Novo. Rio de Janeiro, RJ: Editora FGV, 1999, p. 29. 
necessidades coletivas. ${ }^{113}$

\section{CONCLUSÃo}

Como visto, as reformas administrativas realizadas na quadra histórica de 1930 e 1940 marcam a tentativa de superação de um modelo de Estado Patrimonialista para Burocrático, buscando atribuir maior grau de impessoalidade e eficácia na atuação administrativa, de forma a adequar o Estado ao processo emergente de industrialização e à política desenvolvimentista do governo de Vargas.

Embora os avanços observados com a instituição do sistema de meritocracia para os agentes, controle dos processos e o formalismo, a tentativa de implantação de modelos do sistema comparado, o burocrático-racional de Weber encontrou nas instituições políticoadministrativas e na burocracia brasileira marcada pelo patrimonialismo, autoritarismo e a persistência de práticas clientelistas pelo governo um ambiente pouco propício.

Antes de importar uma superação das mazelas, resultou na formação de uma elite burocrática altamente especializada, marcada por um insulamento e por corporativismo, bem como, uma ampliação de atribuições e autoritarismo. Sob o discurso legitimador da técnica, permaneceu sob influências dos agentes econômicos e do Estado e os demais setores da Administração permanecessem sob a chaga do clientelismo, e não do profissionalismo.

Neste sentido, o Departamento Administrativo do Serviço (DASP) foi o exemplo paradigmático do uso do aparato administrativo como instrumento da política de centralização e controle do Estado Novo sob as unidades federativas, bem como foi o elemento que permitiu ao Governo Vargas empreender a sua política de desenvolvimento nacional, visto que subtraiu as decisões políticas das esferas da representação democrática e lançou a burocracia especializada.

Corrobora para a compreensão que as reformas administrativas, antes de buscar melhor aparelhamento da Administração Pública para a persecução do interesse público, exercem o papel de trazer as

$113 \mathrm{O}$ tema foi amplamente tratado em: MOURA, Emerson Affonso da Costa. Um Fundamento do Regime Administrativo: O Princípio da Persecução do Interesse Público. Dissertação (Mestrado em Direito Constitucional) - Programa de PósGraduação em Direito Constitucional, Universidade Federal Fluminense, Niterói, 2014 (Capítulo II). 
transformações necessárias para as instituições e para a burocracia administrativa adequarem-se aos fins políticos almejados pelo Governo, que não necessariamente coincidem com as necessidades da coletividade.

\section{REFERÊNCIAS}

ABREU, João Capistrano de. Capítulos de História Colonial (15001800). Brasília, DF: Conselho Editorial do Senado Federal, 1998.

AVELLAR, Hélio de Alcântara. História Administrativa do Brasil, Vol. 5. Rio de Janeiro, RJ: DASP, 1970.

BARIANI, Edilson. DASP: Entre a Norma e o Fato. In: Christina W. Andrews; Edilson Bariani (Orgs.). Administração pública no Brasil: breve história política. São Paulo, SP: Editora Unifesp, 2010.

BERNHARD, Regina. El Derecho Administrativo en Países de América del Sur: ¿Coincide la teoria con la realidad? Comparación y evaluación de diferentes sistemas. Anuario de Derecho Constitucional LatinoAmericano, Año 14, 2008.

BOMFIM, Manoel. A América Latina: males de origem. Rio de Janeiro, RJ: Centro Edelstein de Pesquisas Sociais, 2008.

BRESSER-PEREIRA, Luiz Carlos. Do Estado Patrimonial ao Gerencial. In: Afrânio Garcia; Ignacy Sachs; Jorge Wilheim; Paulo Sérgio de M.S. Pinheiro (Orgs.). Brasil: Um Século de Transformações. São Paulo, SP: Cia. das Letras, 2001. . Burocracia Pública e Classes Dirigentes no Brasil. Revista de Sociologia Política, No. 28, 2007. 
. Crise Econômica e Reforma do Estado no Brasil: para uma nova interpretação da América Latina. São Paulo, SP: Editora 34, 1996.

. Plano Diretor da Reforma do Aparelho do Estado. Brasília, DF: Câmara da Reforma do Estado, 1995.

DINIZ, Eliz. Engenharia institucional e políticas públicas: dos conselhos técnicos às câmaras setoriais. In: Dulce Chaves Pandolfi (Org.). Repensando o Estado Novo. Rio de Janeiro, RJ: Editora FGV, 1999.

FAORO, Raymundo. Os Donos do Poder: a formação do patronato político brasileiro. São Paulo, SP: Editora Globo, 2001.

. A Aventura Liberal numa Ordem Patrimonialista. Revista USP, No. 17, 1993.

FERRARI, Levi Bucalem. Burocratas \& Burocracias. São Paulo, SP: Editora Semente, 1981.

FREYRE, Gilberto. Casa-grande \& senzala: formação da família brasileira sob o regime da economia patriarcal. $48^{\mathrm{a}}$ ed. Recife, PE: Fundação Gilberto Freyre, 2003.

GARCIA, Nelson Jahr. O Estado Novo, Ideologia e Propaganda Política: a legitimação do Estado autoritário perante as classes subalternas. São Paulo, SP: Edições Loyola, 1982.

GOUVÊA, Gilda Portugal. Burocracia e Elites Burocráticas no Brasil. São Paulo, SP: Paulicéia, 1994.

HOLANDA, Sérgio Buarque de. Raízes do Brasil. 17ª ed. Rio de Janeiro, RJ: J. Olympio Editora, 1984. 
JAGUARIBE, Hélio. O Nacionalismo na Atualidade Brasileira. Rio de Janeiro, RJ: Ministério da Educação e Cultura, Instituto Superior de Estudos Brasileiros, 1958.

LEROY-BEAULIEU, Paul. De la colonisation chez le peuples modernes. Paris: Guillaumin et Cie Libraires, 1882.

LOEWENSTEIN, Karl. Brazil under Vargas. New York, NY: The Macmillan Co., 1942.

MARTINS, Luciano. Reforma da Administração Pública e Cultura Política no Brasil: uma visão geral. Brasília, DF: Escola Nacional de Administração Pública, 1997.

MOREIRA NETO, Diogo de Figueiredo. Apontamentos sobre a Reforma Administrativa: Emenda Constitucional no 19, de 4 de junho de 1998. Rio de Janeiro, RJ: Renovar, 1999.

MOURA, Emerson Affonso da Costa. Um Fundamento do Regime Administrativo: O Princípio da Persecução do Interesse Público. Dissertação (Mestrado em Direito Constitucional) - Programa de PósGraduação em Direito Constitucional, Universidade Federal Fluminense, Niterói, 2014.

OLIVEIRA, Clarice Gomes de. O Servidor Público Brasileiro: Uma Tipologia da Burocracia. Revista do Serviço Público, Vol. 58, 3, 2007.

OLIVEIRA, Gercina Alves de. A Burocracia Weberiana e a Administração Federal Brasileira. Revista de Administração Pública, Vol. 4, 2, 1970.

OLIVEIRA, Sonale Diane Pastro. A Ditadura Militar e o insulamento burocrático: o SNI, um estudo de caso. Em Tempo de Histórias, no 20 , 2012. 
OLIVEIRA, Lúcia Lippi; VELlOSO, Mônica Pimenta; GOMES, Angela Maria de Castro. Estado Novo: Ideologia e Poder. Rio de Janeiro, RJ: Zahar Editores, 1982.

PRADO JUNIOR, Caio. Formação do Brasil Contemporâneo: colônia. São Paulo, SP: Companhia das Letras, 2011.

MENDEZ, José Luiz. Estudio Introductorio. In: B. Guy Peters. La Política de La Burocracia. Trad. Eduardo L. Suárez Galindo. México: Fondo de cultura económica, 1999.

RABELO, Fernanda Lima. O DASP e o combate à ineficiência nos serviços públicos: a atuação de uma elite técnica na formação do funcionalismo público no Estado Novo (1937-1945). Revista Brasileira de História \& Ciências Sociais, Vol. 3, 6, 2011.

ALVIM, Joaquim Leonel de Rezende; NUNES, Tiago de García. O jeitinho brasileiro, o homem cordial e a impessoalidade administrativa: encontros e desencontros na navegação da máquina pública brasileira. Anais do II seminário dos Estudantes de Pós-graduação em Ciências Sociais do RJ. Rio de Janeiro, RJ: Editora ANPG, 2012.

RIBEIRO, Darcy. O Povo Brasileiro: A Formação e o Sentido do Brasil. São Paulo, SP: Companhia das Letras, 1995.

SALDANHA, Nelson Nogueira. História das Idéias Políticas no Brasil. Brasília, DF: Senado Federal, 2001.

SCHWARTZ, Stuart B. Burocracia e sociedade no Brasil colonial. São Paulo, SP: Editora Perspectiva, 1979.

SCHWARTZMAN, Simon. Bases do Autoritarismo Brasileiro. 4 ed. Rio de Janeiro, RJ: Publit Soluções Editoriais, 2007. 
VIANNA, Hélio. História do Brasil: Período Colonial, Monarquia e República. 12ª ed. São Paulo, SP: Editora da Universidade de São Paulo, 1975.

WAHRLICH, Beatriz M. de Souza. Reforma Administrativa na Era Vargas. Rio de Janeiro, RJ: Instituto de Documentação/Editora da FGV, 1983.

. Reforma Administrativa Federal Brasileira: Passado e Presente.

Revista de Administração Pública, Vol. 8, 2, 1974.

WEBER, Max. O Que é Burocracia? Brasília, DF: Conselho Federal de Administração, s/a.

WEHLING, Arno; WEHLING, Maria José C de M. Formação do Brasil Colonial. Rio de Janeiro, RJ: Editora Nova Fronteira, 1994.

WOLKMER, Antônio Carlos. História do Direito no Brasil. 3ae ed. Rio de Janeiro, RJ: Forense, 2003.

Burocracia Brasileira, Reforma Administrativa e Estado Novo: o papel do aparato administrativo no Governo Vargas Brazilian Administration, Administrative Reform and New State:

the role of administrative apparatus in Vargas Administration Submetido em: 2016-04-20 Aceito em: 2016-07-26 